\title{
Genotoxic and chromatographic analyses of aqueous extracts of Peltodon longipes Kunth ex Benth. (hortelã-do-campo)
}

\author{
Andrielle Wouters Kuhn', Marília Tedesco', Aline Augusti Boligon', Viviane Dal-Souto Frescura ${ }^{2}$, \\ Margareth Linde Athayde ${ }^{1, * *}$, Solange Bosio Tedesco ${ }^{1, *}$
}

\begin{abstract}
${ }^{1}$ Department of Biology, Federal University of Santa Maria, Santa Maria, RS, Brazil, ${ }^{2}$ Department of Academic Coordinator, Federal University of Santa Maria, Campus Cachoeira do Sul, Cachoeira do Sul, RS, Brazil
\end{abstract}

\begin{abstract}
Peltodon longipes is used as a stimulant and emmenagogue. The objective of this study was to perform genotoxic and chromatographic analyses of the extracts of two samples of $P$. longipes, collected from the cities of Santa Maria and Tupanciretã, RS, Brazil. The Allium cepa assay was used to analyze genotoxicity while high-performance liquid chromatography was employed to determine phenolic compounds. The genotoxicity experiment consisted of nine groups each comprising four $A$. cepa bulbs. Bulb roots were developed in distilled water and then transferred for the treatments, for 24 hours, and the negative control remained in water. The treatments were: aqueous extracts at concentrations of 5 and $15 \mathrm{~g} \mathrm{~L}^{-1}$ for each sample, plus four groups treated with $1 \%$ glyphosate, one of which was used as a positive control and the other three for testing DNA damage recovery using water and the extracts of $P$. longipes from Santa Maria. All extracts of $P$. longipes exhibited anti-proliferative potential, although the effect was significantly greater for the extracts from the Tupanciretã sample. This sample also contained the highest amount of rosmarinic acid and kaempferol, which may confer the effects found in these extracts. Only extracts from the Santa Maria sample exhibited genotoxic potential.
\end{abstract}

Uniterms: P. longipes/antiproliferative effect. P. longipes/genotoxic potential. P. longipes/chromatographic analyses. Allium cepa test/genotoxicity.

Peltodon longipes é utilizada como estimulante e emenagoga. Objetivou-se realizar análises genotóxica e cromatográfica dos extratos de duas amostras de $P$. longipes, coletadas nos municípios de Santa Maria e Tupanciretã, RS, Brasil. O teste de Allium cepa foi utilizado para análise da genotoxicidade e a cromatografia líquida de alta eficiência, para determinação dos compostos fenólicos. O experimento de genotoxicidade constou de nove grupos de quatro bulbos de A. cepa. Os bulbos foram enraizados em água destilada e após transferidos para os tratamentos, por 24 horas, permanecendo o controle negativo em água. Os tratamentos foram: extratos aquosos nas concentrações de 5 e $15 \mathrm{~g} \mathrm{~L}^{-1}$ de cada amostra, além de quatro grupos tratados com glifosato $1 \%$, um deles usado como controle positivo e outros três para testar a recuperação de danos ao DNA, utilizando água e os extratos de $P$. longipes da amostra de Santa Maria. Todos os extratos de $P$. longipes demonstraram potencial antiproliferativo, porém o efeito foi significativamente maior para os extratos da amostra de Tupanciretã. Essa amostra também apresentou maior quantidade de ácido rosmarínico e canferol, o que pode estar relacionado com os efeitos encontrados nesses extratos. Somente extratos da amostra de Santa Maria demonstraram potencial genotóxico.

Unitermos: P. longipes/efeito antiproliferativo. P. longipes/potencial genotóxico. P. longipes/análise cromatográfica. Teste de Allium cepa/genotoxicidade.

\footnotetext{
*Correspondence: S. B. Tedesco. Departamento de Biologia. Universidade Federal de Santa Maria. Av. Roraima, 1000 - Bairro Camobi - 97105-900 - Santa Maria - RS, Brazil. E-mail: solatedesco@yahoo.com.br

**In memoriam
} 


\section{INTRODUCTION}

The species Peltodon longipes Kunth ex Benth., belonging to the Lamiaceae family, is found in the Southern region of Brazil and is also referred to as $P$. comaroides Briq. (Briquet, 1989). The plant is known popularly as hortelã-do-campo (wild mint) (Lorenzi, Matos, 2008) and is used in folk medicine as a stimulant and emmenagogue (Mors et al., 2000). Analysis of the tissue of this species by chemical methods has revealed the presence of ursolic acid (Zelnik, Matida, Panizza, 1978/79), a substance present in the group of triterpenic saponins, found predominantly in dicotyledons (Simões et al., 2004). Also, in a study performed by Fronza et al. (2012), five diterpenes were isolated from the plant (7-alpha-acetoxy-royleanone, horminone, royleanone, 7-ketoroyleanone and sugiol) which have shown cytotoxic activity against a type of human pancreatic cancer cell.

Often in ethnic communities and groups, the only resource available for the treatment and prevention of diseases is knowledge of medicinal plants. In some regions of Brazil, even in large cities, plants used in alternative folk medicine are sold in local street markets and stores. This resource is used by the population at large, validating therapeutic information gathered over centuries, even though their chemical constituents remain unknown and little studied (Maciel et al., 2002).

Many laboratory studies have found a large number of antimutagenic and anticarcinogenic compounds in plant species (De Marini, 1998) but despite the therapeutic benefits, some of the constituents of these plants can be potentially toxic, mutagenic, carcinogenic and/or teratogenic (Ping et al., 2012). However, the potential toxicity of medicinal plants is not recognized by the general population or by groups of professionals in traditional medicine (Soetan, Aiyelaagbe, 2009) prompting the need for studies of the genotoxic effects of those medicinal plants not yet evaluated.

The majority of toxicity testing systems depend on small animals, rendering them slow, expensive and the target of much criticism (Fatima, Ahmad, 2006; Siddiqui Tabresz, Ahmad, 2011). However, bioassays are available that use plants as test organism for detecting genotoxicity and cytotoxicity which are easy-to-perform, fast, low-cost and biologically sensitive (Fatima, Ahmad, 2006; Morais, Marin-Morales, 2009). Organisms offering numerous benefits include the onion (Allium cepa L.), ensuring a low-cost assay, ease-of-handling and suitable chromosomal characteristics (Bich, Vedoya, Medvedeff, 2012), facilitating the assessment of chromosome damage and disturbances in the cellular cycle (De Rainho et al., 2010). The in vivo A. cepa test has been used for assessing damage to DNA (Leme, Marin-Morales, 2009) and is considered extremely effective for in situ analysis and monitoring of genotoxicity of a range of different substances (Silva et al., 2004).

Besides toxicity tests, the chromatographic profile of a plant extract is also essential in that it can be considered representative of the chemical complexity of the sample, allowing assessment of the relationship between the chemical information and the characteristics of each plant sample, such as the differentiation between botanically similar species, variability among plants collected from different geographical locations and under different climatic and growing conditions (Chen et al., 2009; Martins, Pereira, Cass, 2011).

Against this background, the objective of the present study was to perform genotoxic and chromatographic analyses of leaf extracts of two samples of $P$. longipes, collected from the cities of Santa Maria and Tupanciretã, Rio Grande do Sul state, Brazil.

\section{MATERIAL AND METHODS}

\section{Genotoxic analysis by the Allium cepa test}

The leaves of two samples of $P$. longipes were collected from two different cities, Santa Maria and Tupanciretã, in Rio Grande do Sul state, Brazil at the geographical locations $29^{\circ} 42^{\prime} 19.8^{\prime}$ 'S $53^{\circ} 43^{\prime} 44.6^{\prime \prime} \mathrm{W}$ and $29^{\circ} 03^{\prime} 56.0^{\prime \prime} \mathrm{S} 53^{\circ} 50^{\prime} 33.8^{\prime \prime} \mathrm{W}$, respectively. Collection was carried out in the summer (December 2013). In February 2014, after drying the plant material, the experimental procedures commenced. The plants were identified by Prof. Dr. Thais do Canto-Dorow and a voucher specimen of each access was deposited at the SMDB (Santa Maria Department of Biology), UFSM, under registration numbers 15406 and 15412 .

The aqueous extracts were prepared at the two concentrations $5 \mathrm{~g} \mathrm{~L}^{-1}$ and $15 \mathrm{~g} \mathrm{~L}^{-1}$, where the lower concentration is generally used by the population for preparing medicinal tea infusions. The dried leaves were placed in boiling water and infused for 10 minutes. The extracts were then strained and left to cool at room temperature.

The experimental set-up consisted of 36 A. cepa bulbs comprising nine groups each with four repetitions. Bulb roots were developed in distilled water and after emergence of the roots, each group of onions was transferred for respective treatment. The first group served as the negative control, remaining in distilled water, while the others were transferred for the following treatments: aqueous extracts 
of $P$. longipes at concentrations of $5 \mathrm{~g} \mathrm{~L}^{-1}$ (Santa Maria sample), $5 \mathrm{~g} \mathrm{~L}^{-1}$ (Tupanciretã sample), $15 \mathrm{~g} \mathrm{~L}^{-1}$ (Santa Maria sample) and $15 \mathrm{~g} \mathrm{~L}^{-1}$ (Tupanciretã sample). Four further groups were treated with 1\% glyphosate (Glyphosate 480 AKB Herbicide), one of which served as the positive control and the remaining three to test possible recovery from DNA damage in distilled water, in aqueous extract of $P$. longipes at the lower concentration, and in aqueous extract of $P$. longipes at the higher concentration, with both the latter prepared with leaves from the Santa Maria sample.

The bulbs were subjected to the treatments for 24 hours and roots subsequently collected and fixed in ethanol: acetic acid $(3: 1)$ for $24 \mathrm{~h}$. The roots were then refrigerated in $70 \%$ alcohol until slide preparation. Two slides were produced per bulb for each treatment and control. For slide preparation, one root per slide was used, i.e. a total of two roots per bulb were analyzed. These were hydrolyzed in $1 \mathrm{~mol} / \mathrm{L} \mathrm{HCl}$ for five minutes and then washed in distilled water and stained with $2 \%$ acetic orcein. The meristematic region of the roots was fragmented with the aid of histological needles, crushed according to the technique of Guerra and Souza (2002), and coverslips placed over the material. The analysis included 500 cells per root, 1000 per bulb, 4000 cells per treatment, giving a total of 36000 cells at experiment endpoint. The slides were assessed using an optical light microscope (LEICA) with a $40 \mathrm{X}$ objective by observing cells in interphase, prophase, metaphase, anaphase, telophase and possible occurrence of chromosome changes during the cellular cycle. After analysis of slides, the Mitotic Index (MI) was determined by calculating the number of cells in division / total number of cells analyzed x 100 .

\section{High performance liquid chromatography (HPLC-DAD)}

High performance liquid chromatography was employed for the determination and quantification of the phenolic compounds present in the aqueous extracts of $P$. longipes leaves. The analysis was performed at the Phytochemistry Laboratory of the Department of Industrial Pharmacy of the Federal University of Santa Maria, Santa Maria, Rio Grande Sul state.

\section{Chemicals, apparatus and general procedures}

All chemical were analytical grade. Acetonitrile, formic acid, gallic acid, chlorogenic acid, caffeic acid, ellagic acid and rosmarinic acid were purchased from Merck (Darmstadt, Germany). Quercetin and kaempferol were acquired from Sigma Chemical Co. (St. Louis, MO, USA). High performance liquid chromatography (HPLC-
DAD) was performed with a Shimadzu Prominence Auto Sampler (SIL-20A) HPLC system (Shimadzu, Kyoto, Japan), equipped with Shimadzu LC-20AT reciprocating pumps connected to a DGU 20A5 degasser with a CBM $20 \mathrm{~A}$ integrator, SPD-M20A diode array detector and running LC solution 1.22 SP1 software.

\section{Quantification of compounds by HPLC-DAD}

Reversed phase chromatographic analyses were carried out under gradient conditions using a $\mathrm{C}_{18}$ column $(4.6 \mathrm{~mm} \times 150 \mathrm{~mm}$ ) packed with $5 \mu \mathrm{m}$ diameter particles; the mobile phase was water containing $1 \%$ formic acid (A) and acetonitrile (B), and the composition gradient was: $13 \%$ of $\mathrm{B}$ up to $10 \mathrm{~min}$ and changed thereafter to obtain $20 \%, 30 \%, 50 \%, 60 \%, 70 \%, 20 \%$ and $10 \%$ B at $20,30,40,50,60,70$ and $80 \mathrm{~min}$, respectively, following the method described by Kamdem et al. (2013) with slight modifications. P. longipes (Santa Maria and Tupanciretã) aqueous extracts and mobile phase were filtered through a $0.45 \mu \mathrm{m}$ membrane filter (Millipore) and then degassed by an ultrasonic bath prior to use. The P. longipes (Santa Maria and Tupanciretã) extracts were analyzed at a concentration of $5 \mathrm{~g} \mathrm{~L}^{-1}$ and $15 \mathrm{~g} \mathrm{~L}^{-1}$. The flow rate was $0.6 \mathrm{~mL} / \mathrm{min}$, injection volume $50 \mu \mathrm{L}$ and wavelengths were $254 \mathrm{~nm}$ for gallic acid, $327 \mathrm{~nm}$ for caffeic, chlorogenic, rosmarinic and ellagic acids, and $366 \mathrm{~nm}$ for quercetin and kaempferol. All the samples and mobile phase were filtered through a $0.45 \mu \mathrm{m}$ membrane filter (Millipore) and then degassed by ultrasonic bath prior to use. Stock solutions of standard references were prepared in the HPLC mobile phase at a concentration range of $0.025-0.300 \mathrm{mg} / \mathrm{mL}$ for quercetin and kaempferol; and $0.050-0.450 \mathrm{mg} / \mathrm{mL}$ for ellagic, gallic, rosmarinic, chlorogenic and caffeic acids. Chromatography peaks were confirmed by comparing their retention times with those of reference standards and by DAD spectra (200 to $600 \mathrm{~nm}$ ). Calibration curves were: for gallic acid: $\mathrm{Y}=12674 \mathrm{x}+1375.6(\mathrm{r}=0.9998)$; chlorogenic acid: $\mathrm{Y}=11863 \mathrm{x}+1274.9(\mathrm{r}=0.9998)$; caffeic acid: $\mathrm{Y}=13592 \mathrm{x}+1367.1(\mathrm{r}=0.9999)$; ellagic acid: $\mathrm{Y}=13286 \mathrm{x}+1264.1(\mathrm{r}=0.9997)$; rosmarinic acid: $\mathrm{Y}$ $=12837 \mathrm{x}+1364.5(\mathrm{r}=0.9994)$; quercetin: $\mathrm{Y}=13627 \mathrm{x}+$ $1292.5(\mathrm{r}=0.9996)$ and kaempferol: $\mathrm{Y}=11794 \mathrm{x}+1326.6$ $(\mathrm{r}=0.9999)$. All chromatography operations were carried out at ambient temperature and in triplicate.

The limit of detection (LOD) and limit of quantification (LOQ) were calculated based on the standard deviation of the responses and the slope using three independent analytical curves. LOD and LOQ were calculated as 3.3 and $10 \sigma / \mathrm{S}$, respectively, where $\sigma$ is the standard deviation of the response and $\mathrm{S}$ is the slope of the calibration curve (Boligon et al., 2013). 


\section{Statistical analysis}

The data were submitted to analysis of variance (ANOVA) and the means were compared by the ScottKnott test at 5\% probability using the Assistat 7.7 beta software program.

\section{RESULTS AND DISCUSSION}

\section{Genotoxic analysis by the Allium cepa test}

According to the results obtained in the genotoxicity analysis (Table I), the highest mitotic index (MI) value was observed for the negative control in distilled water (MI $=11.7 \%$ ). For the treatments using the aqueous extracts prepared with $P$. longipes leaves, significantly lower mitotic indexes for both concentrations and samples were observed compared with the negative control, confirming that the plant extract exhibited anti-proliferative potential. The same effect was found by Sturbelle et al. (2010) in a study using the onion test to assess the concentrations of babosa solution (Aloe vera L.), 40 and $400 \mathrm{~mL} \mathrm{~L}^{-1}$, whose results showed inhibition of cell division following application of the solutions on meristematic cells of onion.

Given the fact that the extracts studied were from plants collected from different cities, the results of treatments at the same concentration involving different samples differed significantly in mitotic index. By contrast, treatments with extracts from the same sample, even at different concentrations, showed similar effects on the cellular division of $A$. cepa. The anti-proliferative effect of the treatments derived from leaves collected at the Tupanciretã sample was found to be significantly greater $(\mathrm{MI}=1.32$ and $0.87 \%)$. These results may be explained by possible variations in the levels of production of secondary metabolites of the plants studied, since it is known that such metabolites constitute a chemical interface between the plants and also that their synthesis is often affected by the surrounding environment and environmental conditions (Kutchan, 2001).

With regard to the mitotic indexes of the positive controls ( $1 \%$ glyphosate) and of treatments with glyphosate testing the possibility of recovery from damage to genetic material by subsequent use of distilled water or P. longipes extracts (Santa Maria sample), no significant differences between them were evident, with similar rates of cellular division being observed between the positive control and these three recovery treatments.

Regarding the percentage alterations found (Table II and Figure 1), the positive control with 1\% glyphosate caused the greatest percentage damage to DNA $(0.72 \%)$, differing significantly to the other treatments studied. This was due to the ability to induce chromosome alterations in meristematic cells of $A$. cepa using glyphosate, a phenomenon also observed by Souza et al. (2010).

Among the treatments with extracts of $P$. longipes at the standard $\left(5 \mathrm{~g} \mathrm{~L}^{-1}\right)$ and higher $\left(15 \mathrm{~g} \mathrm{~L}^{-1}\right)$ concentrations, a statistically significant difference in percentage chromosomal alterations was observed between the aqueous extracts of plants from different samples. Treatments with extracts of leaves from Santa Maria were associated with a significantly higher percentage of chromosome alterations compared to the control in distilled water, confirming genotoxic potential. By contrast, the treatments with aqueous extracts of plants collected from Tupanciretã showed no significant difference compared to the negative control. Thus, the treatments with the extracts from the Tupanciretã sample, besides displaying good

TABLE I - Total number of cells, cells in interphase, cells in division and mitotic index (MI\%) observed on the genotoxicity test of two samples of Peltodon longipes

\begin{tabular}{|c|c|c|c|c|}
\hline Treatments & $\begin{array}{l}\text { Total Number } \\
\text { of Cells }\end{array}$ & $\begin{array}{l}\text { Cells in } \\
\text { Interphase }\end{array}$ & $\begin{array}{l}\text { Cells in } \\
\text { Division }\end{array}$ & $\mathrm{MI} \%$ \\
\hline Negative Control (distilled water) & 4000 & 3532 & 468 & $11.7 \mathrm{a}$ \\
\hline Extract $5 \mathrm{~g} \mathrm{~L}^{-1}(\mathrm{SM})$ & 4000 & 3808 & 192 & $4.8 \mathrm{~b}$ \\
\hline Extract $5 \mathrm{~g} \mathrm{~L}^{-1}(\mathrm{TP})$ & 4000 & 3947 & 53 & $1.32 \mathrm{c}$ \\
\hline Extract $15 \mathrm{~g} \mathrm{~L}^{-1}(\mathrm{SM})$ & 4000 & 4779 & 221 & $5.52 \mathrm{~b}$ \\
\hline Extract $15 \mathrm{~g} \mathrm{~L}^{-1}(\mathrm{TP})$ & 4000 & 3965 & 35 & $0.87 \mathrm{c}$ \\
\hline Positive Control (glyphosate 1\%) & 4000 & 3901 & 99 & $2.47 \mathrm{c}$ \\
\hline Glyphosate + Recovery in distilled water & 4000 & 3945 & 55 & $1.37 \mathrm{c}$ \\
\hline Glyphosate + Recovery in extract $5 \mathrm{~g} \mathrm{~L}^{-1}(\mathrm{SM})$ & 4000 & 3895 & 105 & $2.62 \mathrm{c}$ \\
\hline Glyphosate + Recovery in extract $15 \mathrm{~g} \mathrm{~L}^{-1}(\mathrm{SM})$ & 4000 & 3961 & 39 & $0.97 \mathrm{c}$ \\
\hline
\end{tabular}

$\mathrm{SM}=$ Santa Maria sample; TP = Tupanciretã sample; MI = Mitotic Index. Means followed by the same letter do not differ significantly at the $5 \%$ level, according to the Scott-Knott test. 
TABLE II - Chromosomal alterations observed on the genotoxicity test of two samples of Peltodon longipes

\begin{tabular}{|c|c|c|c|c|c|}
\hline \multirow[b]{2}{*}{ Treatments } & \multirow{2}{*}{$\begin{array}{c}\text { Total } \\
\text { cells with } \\
\text { alterations }\end{array}$} & \multicolumn{3}{|c|}{ Chromosomal alterations in the cell cycle } & \multirow{2}{*}{$\begin{array}{l}\text { Chromosomal } \\
\text { alterations \% }\end{array}$} \\
\hline & & $\mathrm{MN}$ & Q & $P$ & \\
\hline Negative Control (distilled water) & 0 & 0 & 0 & 0 & $0 \mathrm{c}$ \\
\hline Extract $5 \mathrm{~g} \mathrm{~L}^{-1}(\mathrm{SM})$ & 12 & 0 & 1 & 11 & $0.3 \mathrm{~b}$ \\
\hline Extract $5 \mathrm{~g} \mathrm{~L}^{-1}(\mathrm{TP})$ & 2 & 2 & 0 & 0 & $0.05 \mathrm{c}$ \\
\hline Extract $15 \mathrm{~g} \mathrm{~L}^{-1}(\mathrm{SM})$ & 14 & 3 & 2 & 9 & $0.35 \mathrm{~b}$ \\
\hline Extract $15 \mathrm{~g} \mathrm{~L}^{-1}(\mathrm{TP})$ & 2 & 2 & 0 & 0 & $0.05 \mathrm{c}$ \\
\hline Positive Control (glyphosate 1\%) & 29 & 8 & 7 & 14 & $0.72 \mathrm{a}$ \\
\hline Glyphosate + Recovery in distilled water & 3 & 0 & 0 & 3 & $0.07 \mathrm{c}$ \\
\hline Glyphosate + Recovery in extract $5 \mathrm{~g} \mathrm{~L}^{-1}(\mathrm{SM})$ & 12 & 1 & 5 & 6 & $0.3 \mathrm{~b}$ \\
\hline Glyphosate + Recovery in extract $15 \mathrm{~g} \mathrm{~L}^{-1}(\mathrm{SM})$ & 4 & 1 & 2 & 1 & $0.1 \mathrm{c}$ \\
\hline
\end{tabular}

$\mathrm{MN}=$ Micronucleus in interphase $\mathrm{Q}=$ chromosome breaks; $\mathrm{P}=$ chromosome bridge $; \mathrm{SM}=$ Santa Maria sample $\mathrm{TP}=$ Tupanciretã sample. Means followed by the same letter do not differ significantly at the $5 \%$ level, according to the Scott-Knott test.
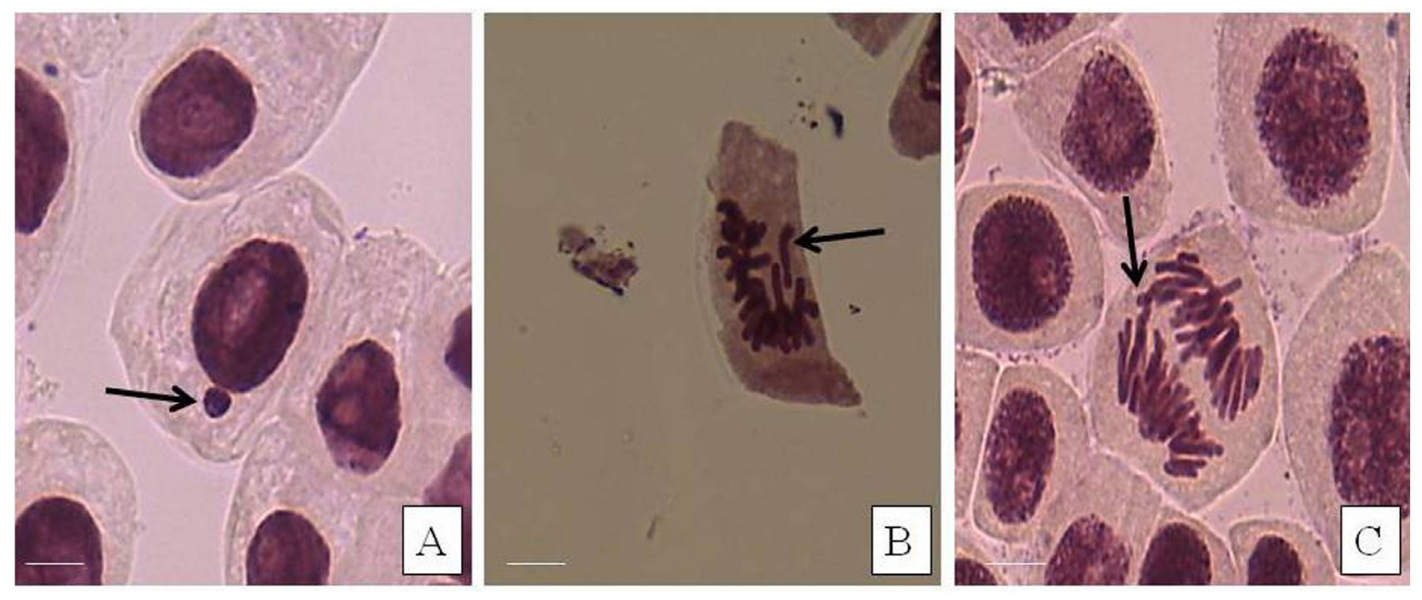

FIGURE 1 - Chromosomal alterations in meristematic cells of Allium cepa roots a) Arrow indicates micronucleus in interphase; b) Arrow indicates chromosome break in metaphase; c) Arrow indicates chromosome bridge in anaphase. Scale represent $10 \mu \mathrm{m}$.

anti-proliferative potential showed no genotoxic activity.

This presence of an anti-proliferative effect and absence of genotoxicity was also observed by Frescura et al. (2013) in tests using extracts of Psychotria brachypoda (Müll Arg.) Britton on the A. cepa assay, showing lower MI following treatment with the extracts at both the lower $(5 \mathrm{~g}$ $\left.\mathrm{L}^{-1}\right)$ and higher $\left(20 \mathrm{~g} \mathrm{~L}^{-1}\right)$ concentrations studied as well as very few chromosomal alterations, thereby confirming the absence of genotoxic potential. Extracts of Pterocaulum polystachyum DC. (Knoll et al., 2006) showed similar effects when analyzed by the same test, while the species Baccharis trimera (Less) DC. and Baccharis articulata (Lam.) Pers. (Fachinetto and Tedesco, 2009) exhibited anti-proliferative activity but also genotoxic potential, akin to the results seen for the extracts of $P$. longipes from the Santa Maria sample.

For treatments aimed at detecting a possible antigenotoxic effect by recovery using distilled water and extracts of $P$. longipes (Santa Maria sample) at both lower and higher concentrations, the three treatments were associated with significantly lower manifestation of chromosomal alterations in meristematic cells of $A$. cepa than the positive control. Use of distilled water led to good recovery of cell division, with a $0.65 \%$ reduction in chromosomal alterations compared to the positive control which had $0.72 \%$ chromosomal changes. Similar results were found by Frescura et al. (2013) who also assessed the recovery of onion roots through the application of distilled water after the use of glyphosate. In this case, water was also shown to be effective for recovering from damage to DNA, with a decrease in chromosomal changes from 102 (3\% glyphosate) to 41 (glyphosate following the application of water).

In the recovery treatments based on the application of $P$. longipes extracts, only recovery with the $5 \mathrm{~g} \mathrm{~L}^{-1}$ extract (Santa Maria sample) differed significantly from 
recovery in water, but proved less effective for reducing the damage caused by glyphosate. On the other hand, application of the $15 \mathrm{~g} \mathrm{~L}^{-1}$ extract after glyphosate treatment did not differ significantly to recovery in water, showing the same effect. Although the number of chromosomal alterations was significantly higher in some treatments compared to the negative control, it is should be noted that all values were relatively low, representing less than $1 \%$ of the total cells analyzed per treatment (Table II).

\section{High Performance Liquid Chromatography (HPLC-DAD)}

Despite the great importance of medicinal plants for pharmacological research and in the development of drugs, studies elucidating their constituents remain scarce.

HPLC fingerprinting of $P$. longipes (Santa Maria and Tupanciretã) extracts revealed the presence of gallic acid $\left(t_{R}=9.86\right.$ min; peak 1), chlorogenic acid $\left(t_{R}=19.47\right.$ min; peak 2$)$, caffeic acid $\left(t_{R}=24.98\right.$ min; peak 3$)$, ellagic acid $\left(t_{R}=33.17\right.$; peak 4$)$, rosmarinic acid $\left(t_{R}=38.06\right.$ min; peak 5), quercetin $\left(t_{R}=41.25\right.$ min; peak 6) and kaempferol $\left(t_{R}=56.61\right.$ min; peak 7) (Figure 2 and Table III).

Comparison of the chromatographic profiles of the extracts of the two different samples (Santa Maria and Tupanciretã) revealed differences in the amounts of some compounds, particularly for rosmarinic acid (Figure 2 peak 5) and kaempferol (Figure 2 - peak 7), for which the difference was more evident. In these two cases, the quantity of the compounds was higher in the Tupanciretã sample at both concentrations.

In in vitro study conducted with human fibroblast cells using the Western blot test, it was suggested that rosmarinic acid inhibits genes related to NF-KB promoter detected in cancer (Lee et al., 2006), which may explain, in part, the most significant anti-proliferative potential in extracts of the plants from the Tupanciretã sample. Besides the possible antiproliferative activity of rosmarinic acid, other biological activities have been attributed to the compound, such as anti-tumoral (Mckay and Blumberg, 2006) and also antimutagenic (Furtado et al., 2008) properties. With regard to flavonoids, kaempferol included, these are generally considered beneficial, where some medicines are produced from them and used to treat circulatory diseases, hypertension, and to act as a cofactor of vitamin $\mathrm{C}$, while also exert antitumoral, antiviral, anti-hemorrhagic, hormonal, anti-inflammatory, antimicrobial and antioxidant action (Simões et al., 2004).

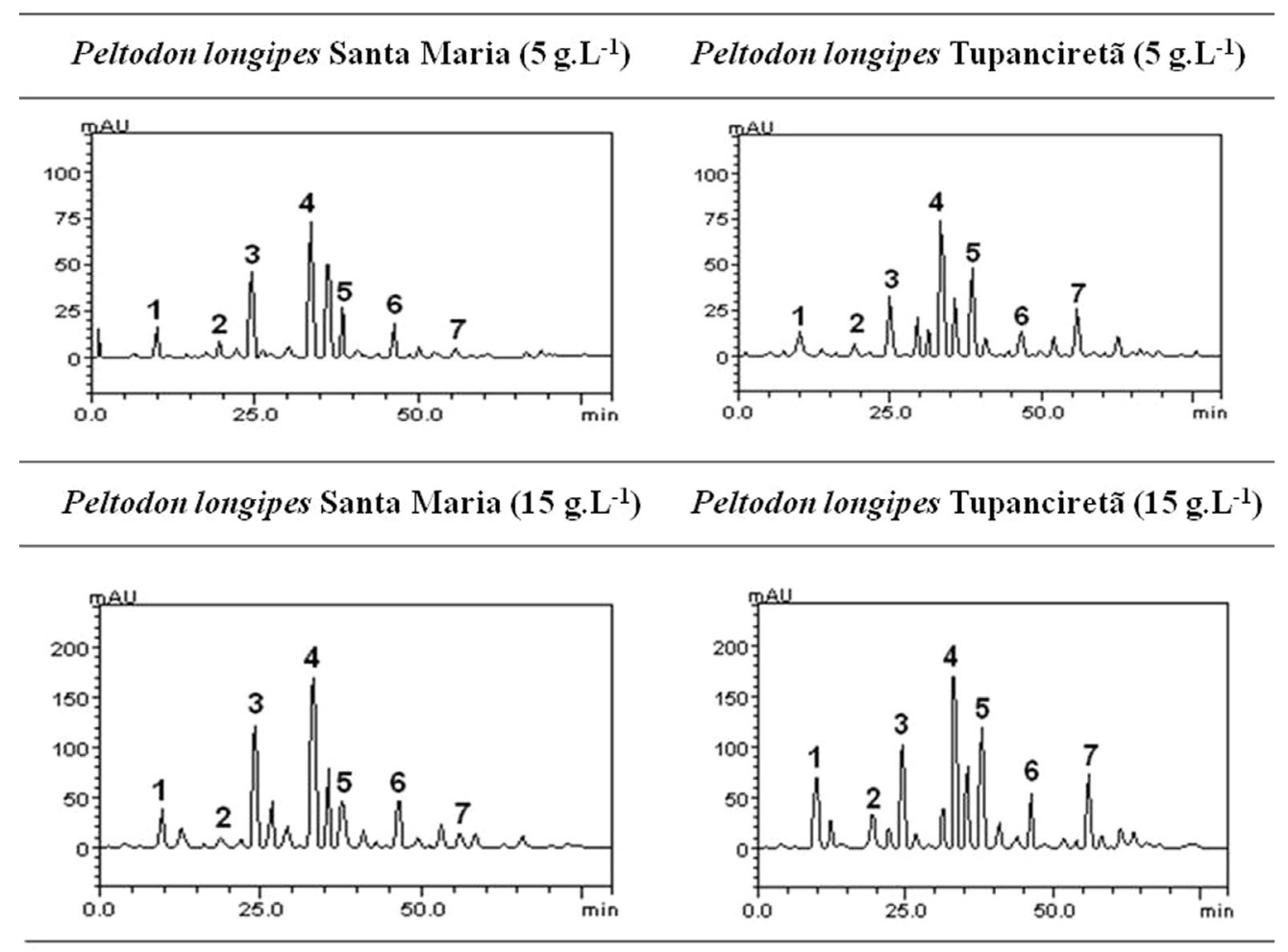

FIGURE 2 - Representative high performance liquid chromatography profile of Peltodon longipes (Santa Maria and Tupanciretã). Gallic acid (peak 1), chlorogenic acid (peak 2), caffeic acid (peak 3), ellagic acid (peak 4), rosmarinic acid (peak 5), quercetin (peak 6) and kaempferol (peak 7). 
TABLE III - Phenolic acid and flavonoid composition of Peltodon longipes (Santa Maria and Tupanciretã) aqueous extract

\begin{tabular}{lcccccc}
\hline Compounds & $\begin{array}{c}\mathrm{SM}\left(5 \mathrm{~g} \mathrm{~L}^{-1}\right) \\
\mathrm{mg} \mathrm{g}^{-1}\end{array}$ & $\begin{array}{c}\mathrm{TP}\left(5 \mathrm{~g} \mathrm{~L}^{-1}\right) \\
\mathrm{mg} \mathrm{g}^{-1}\end{array}$ & $\begin{array}{c}\mathrm{SM}\left(15 \mathrm{~g} \mathrm{~L}^{-1}\right) \\
\mathrm{mg} \mathrm{g}^{-1}\end{array}$ & $\begin{array}{c}\mathrm{TP}\left(15 \mathrm{~g} \mathrm{~L}^{-1}\right) \\
\mathrm{mg} \mathrm{g}^{-1}\end{array}$ & $\begin{array}{c}\mathrm{LOD} \\
\mu \mathrm{g} \mathrm{mL}^{-1}\end{array}$ & $\begin{array}{c}\mathrm{LOQ} \\
\mu \mathrm{gL}^{-1}\end{array}$ \\
\hline Gallic acid & $1.22 \mathrm{e}$ & $1.36 \mathrm{e}$ & $2.41 \mathrm{e}$ & $4.12 \mathrm{~d}$ & 0.017 & 0.056 \\
Chlorogenic acid & $0.71 \mathrm{f}$ & $0.64 \mathrm{~g}$ & $0.65 \mathrm{f}$ & $2.21 \mathrm{f}$ & 0.009 & 0.029 \\
Caffeic acid & $3.47 \mathrm{~b}$ & $2.73 \mathrm{c}$ & $7.00 \mathrm{~b}$ & $6.19 \mathrm{c}$ & 0.031 & 0.101 \\
Ellagic acid & $4.28 \mathrm{a}$ & $4.50 \mathrm{a}$ & $8.77 \mathrm{a}$ & $8.72 \mathrm{a}$ & 0.028 & 0.092 \\
Rosmarinic acid & $1.97 \mathrm{c}$ & $3.48 \mathrm{~b}$ & $3.12 \mathrm{~d}$ & $6.84 \mathrm{~b}$ & 0.026 & 0.085 \\
Quercetin & $1.42 \mathrm{~d}$ & $1.22 \mathrm{f}$ & $3.18 \mathrm{c}$ & $2.89 \mathrm{e}$ & 0.014 & 0.045 \\
Kaempferol & $0.63 \mathrm{~g}$ & $2.08 \mathrm{~d}$ & $0.59 \mathrm{~g}$ & $4.10 \mathrm{~d}$ & 0.035 & 0.115 \\
\hline
\end{tabular}

$\mathrm{SM}=$ Santa Maria sample; $\mathrm{TP}=$ Tupanciretã sample; $\mathrm{LOD}=$ Limit of Detection; $\mathrm{LOQ}=$ Limit of Quantification. Means followed by the same letter do not differ significantly at the $5 \%$ level, according to the Scott-Knott test.

\section{CONCLUSION}

Based on the results obtained on the A. cepa test, it can be concluded that the aqueous extracts of $P$. longipes leaves from the two samples studied, at both concentrations, exhibited anti-proliferative potential, although this effect was significantly greater for the extracts from the Tupanciretã sample. This access also showed the highest amount of rosmarinic acid and kaempferol, which may confer the anti-proliferative effect and absence of genotoxicity of their extracts. Regarding the extracts from the Santa Maria sample, besides exerting a lesser antiproliferative effect, they exhibited genotoxic potential.

\section{ACKNOWLEDGMENTS}

This study was supported by the Fundação de Amparo à Pesquisa do Estado do Rio Grande do Sul (FAPERGS/ CAPES) and Coordenação de Aperfeiçoamento de Pessoal de Nível Superior (CAPES) to whom we express our gratitude.

\section{REFERENCES}

BICH, G.A.; VEDOYA, M.C.; MEDVEDEFF, M.G. Formulación antifúngica basada en solución saturada de sacarosa: evaluación de su potencial actividad genotóxica empleando la prueba de Allium cepa. Rev. Ciênc. Tecnol., v.14, n.18, p.39-43, 2012.

BOLIGON, A.A.; KUBIÇA, T.F.; MARIO, D.N.; BRUM, T.F.; PIANA, M.; WEIBLEN, R.; LOVATO, L.; ALVES, S.H.; SANTOS, R.C.V.; ALVES, C.F.S.; ATHAYDE, M.L. Antimicrobial and antiviral activity-guided fractionation from Scutia buxifolia Reissek extracts. Acta Physiol. Plant., v.35, n.7, p.2229-2239, 2013.
BRIQUET, J. Fragmenta monographiae labiaturum I. Bull. Soc. Bot. Genève, v.5, p.20-122, 1889.

CHEN, J.; LU, Y.-H.; WEI, D.-Z.; ZHOU, X.-L. Establishment of a fingerprint of raspberries by LC. Chromatographia, v.70, n.5-6, p.981, 2009.

DE MARINI, D.M. Dietary interventions of human carcinogenesis. Mutat. Res., v.400, n.1-2, p.457-465, 1998.

DE RAINHO, C.; KAEZER, A.; AIUB, C. FELZENSZWALB, I. Ability of Allim cepa L. root tips and Tradescantia pallida var. purpurea in $N$-nitrosodiethylamine genotoxicity and mutagenicity evaluation. An. Acad. Bras. Ciênc., v.82, n.4, p.925-932, 2010.

FACHINETTO, J.M.; TEDESCO, S.B. Atividade antiproliferativa e mutagênica dos extratos aquosos de Baccharis trimera (Less.) A. P. de Candolle e Baccharis articulata (Lam.) Pers. (Asteraceae) sobre o sistema teste de Allium cepa. Rev. Bras. Plantas Med., v.11, n.4, p.360-367, 2009.

FATIMA, R.; AHMAD, M. Genotoxicity of industrial wastewaters obtained from two different pollution sources in northern India: a comparison of three bioassays. Mutat. Res., v.909, n.1, p.81-91, 2006.

FURTADO, M.A.L.; ALMEIDA, C.F.; FURTADO, R.A.; CUNHA, W.R.; TAVARES, D.C. Antimutagenicity of rosmarinic acid in Swiss mice evaluated by the micronucleus assay. Mutat. Res., v.657, n.2, p.150-154, 2008.

FRESCURA, V.D.; KUHN, A.W.; LAUGHINGHOUSE IV, H.D.; PARANHOS, J.T.; TEDESCO, S.B. Post-treatment with plant extracts used in Brazilian folk medicine caused a partial reversal of the antiproliferative effect of glyphosate in the Allium cepa test. Biocell, v.37, n.2, p.23-28, 2013. 
FRONZA, M.; LAMY, E.; GÜNTHER, S.; HEINZMANN, B.; LAUFER, S.; MERFORT, I. Abietane diterpenes induce cytotoxic effects in human pancreatic cancer cell line MIA PaCa-2 through different modes of action. Phytochemistry, v.78, p.107-119, 2012.

GUERRA, M.; SOUZA, M.J. Como observar cromossomos - um guia de técnicas em citogenética vegetal, animal e humana. Ribeirão Preto: FUNPEC, 2002. 131 p.

KAMDEM, J.P.; OLALEKAN, E.O.; HASSAN, W.; KADE, I.J.; YETUNDE, O.; BOLIGON, A.A.; ATHAYDE, M.L.; SOUZA, D.O.; ROCHA, J.B.T. Trichilia catigua (Catuaba) bark extract exerts neuroprotection againstoxidative stress induced by different neurotoxic agents in rat hippocampal slices. Ind. Crops Prod., v.50, p.625-632, 2013.

KNOLL, M.F.; SILVA, A.C.F.; CANTO-DOROW, T.S.; TEDESCO, S.B. Effects of Pterocaulon polystachyum DC. (Asteraceae) on onion (Allium cepa) root-tip cells. Genet. Mol. Biol., v.29, n.3, p.539-542, 2006.

KUTCHAN, T.M. Ecological arsenal and developmental dispatcher. The paradigm of secondary metabolism. Plant Physiol., v.125, n.1, p.58-60, 2001.

LEE, J.; JUNG, E.; KIM, Y.; LEE, J.; PARK, J.; HONG, S.; HYUN, C.G.; PARK, D.; KIM, Y.S. Rosmarinic acid as a downstream inhibitor of IKK-beta in TNF-alpha-induced upregulation of CCL 11 and CCR3. Br. J. Pharmacol., v.148, n.3, p.366-375, 2006.

LEME, D.M.; MARIN-MORALES, M.A. Allium cepa test in environmental monitoring: a review on its application. Mutat. Res., v.682, n.1, p.71-81, 2009.

LORENZI, H.; MATOS, F.J.A. Plantas medicinais no Brasil: nativas e exóticas. Nova Odessa: Editora Instituto Plantarum, 2008. 544 p.

MACIEL, M.A.M.; PINTO, A.C.; VEIGA JR, V.F.; GRYNBERG, N.F.; ECHEVARRIA, A. Plantas medicinais: a necessidade de estudos multidisciplinares. Quim. Nova, v.25, n.3, p.429-438, 2002.

MARTINS, L.R.R.; PEREIRA, E.R.F.; CASS, Q.B. Chromatographic profiles of Phyllanthus aqueous extracts samples: a proposition of classification using chemometric models. Anal. Bioanal. Chem., v.400, n.2, p.469-481, 2011.
MCKAY, D.L.; BLUMBERG, J.B. A review of the bioactivity and potential health benefits of peppermint tea (Mentha piperita L.). Phytother. Res., v.20, n.8, p.619-633, 2006.

MORAIS, D.; MARIN-MORALES, M. Allium cepa test in environmental monitoring: A review on its application. Mutat. Res., v.682, n.1, p.71-81, 2009.

PING, K.Y.; DARAH, I.; YUSUF, U.K.; YENG, C.; SASIDHARAN, S. Genotoxicity of Euphorbia hirta: an Allium cepa Assay. Molecules, v.17, n.7, p.7782-7791, 2012.

SIDDIQUI, A.; TABRESZ, S.; AHMAD, M. Validation of plant based bioassays for the toxicity testing of Indian waters. Environ. Monit. Assessment., v.179, n.1-4, p.241-253, 2011.

SILVA, C.R.; MONTEIRO, M.R.; CALDEIRA-DE-ARAÚJO, A.; BEZERRA, R.J.A.C. Absence of mutagenic and citotoxic potentiality of senna (Cassia angustifolia Vahl.) evaluated by microbiological tests. Rev. Bras. Farmacogn., v.1, suppl.1, p.1-3, 2004.

SIMÕES, C.M.O.; SCHENKEL, E.P.; GOSMANN, G.; MELLO, J.C.P.; MENTZ, L.A.; PETROVICK, P.R. (Eds.). Farmacognosia: da planta ao medicamento. 6.ed. Porto Alegre: Ed. UFSC, 2004. 821 p.

SOETAN, K.O.; AIYELAAGBE, O.O. The need for bioactivitysafety evaluation and conservation of medicinal plants: a review. J. Med. Plants Res., v.3, p.324-328, 2009.

STURBELLE, R.T.; PINHO, D.S.; RESTANI, R.G.; OLIVEIRA, G.R.; GARCIAS, G.L.; MARTINO-ROTH, M.G. Avaliação da atividade mutagênica e antimutagênica da Aloe vera em teste de Allium cepa e teste de micronúcleo em linfócitos humanos binucleados. Rev. Bras. Farmacogn., v.20, n.3, p.409-415, 2010.

ZELNIK, R.; MATIDA, A.K.; PANIZZA, S. Chemistry of the Brazilian Labiatae. The occurence of ursolic acid in Peltodon radicans Pohl. Mem. Inst. Butantan, v.42, p.357361, 1978/79.

Received for publication on $29^{\text {th }}$ January 2015 Accepted for publication on $24^{\text {th }}$ June 2015 